\title{
ANALYSIS OF THE COMPOSITION OF BRAZILIAN PROPOLIS EXTRACTS BY CHROMATOGRAPHY AND EVALUATION OF THEIR IN VITRO ACTIVITY AGAINST GRAM-POSITIVE BACTERIA
}

\author{
Alexandra C. H. F. Sawaya ${ }^{1}$; Kirllian S. Souza ${ }^{1}$; Maria C. Marcucci² ${ }^{2}$ Ildenize B. S. Cunha ${ }^{1}$; Mario T. Shimizu ${ }^{1 *}$ \\ ${ }^{1}$ Universidade São Francisco, Bragança Paulista, SP, Brasil; ${ }^{2}$ Universidade Bandeirante de São Paulo, São Paulo, SP, Brasil. \\ Submitted: July 28, 2003; Returned to authors: February 19, 2004; Approved: May 20, 2004.
}

\begin{abstract}
Brazilian propolis from São Paulo state was submitted to extraction using several solvents, resulting in extracts with different composition. These extracts were submitted to Thin Layer Chromatography (TLC). Bioauthographic analysis of the TLC plates identified fractions with inhibitory activity, which were then analysed by High Performance Liquid Chromatography (HPLC). In vitro assays, commonly used to evaluate the activity of propolis against Gram-positive bacteria, were compared to determine which rendered the most consistent results. The bactericidal activity of these extracts were analysed by Serial Dilution in Tubes and Agar Plate Diffusion. Serial Dilution in Tubes obtained the most consistent results, with the Minimal Bactericidal Concentration of the extracts ranging between 2.5 and $20.0 \mathrm{mg} / \mathrm{mL}$, for the species of Gram-positive bacteria tested. The results of the Agar Plate Diffusion were directly proportional to the hydro-solubility of the extracts and did not evaluate their bactericidal activity correctly. The bactericidal activity of this sample of propolis was due to the combined effect of several components that were identified by HPLC and were best extracted using $50 \%$ ethanol as a solvent.
\end{abstract}

Key words: propolis, thin layer chromatography, bioauthography, high performance liquid chromatography, extraction methods, minimal bactericidal concentration

\section{INTRODUCTION}

Propolis, a resin collected by bees from plants around their hives, is used to maintain the hive environment aseptic and to reinforce the honeycombs. In Europe and North America these resins are mainly collected from trees of the Populus species (9) and the antimicrobial activity is mainly due to flavonoids. In tropical regions these plant species are not native. Therefore, Apis mellifera bees, as well as native stingless bees, must find other plant sources. Studies of South American propolis samples from different regions have attempted to determine their plant origins and chemical composition $(2,12,17,21)$.

Several studies have determined the activity of European and Brazilian propolis against Gram-positive bacteria, using mainly Serial Dilution tests and Agar Plate Diffusion tests. The Bioautographic analysis of Thin Layer Chromatographic
(TLC) plates has also been reported. The variety of methods used to evaluate the antimicrobial activity of propolis samples makes it difficult to compare the results of different authors. A previous paper (19) determined which solvent best extracted components with activity against species of Candida, identifying some of these components by chromatographic methods, as well as comparing the microbiological methods commonly used to evaluate the activity of propolis against Candida yeast.

The objectives of this paper were: (a) to determine the composition of the solvent which best extracted bactericidal compounds from crude propolis; (b) to identify components with antimicrobial activity, using chromatographic techniques and (c) to determine which microbiological assay best evaluated the activity of propolis extracts with varying composition against several Gram-positive bacteria.

*Corresponding author. Mailing address: Universidade São Francisco, Av. São Francisco de Assis, 218. 12916-390, Bragança Paulista, SP, Brasil. Fax (+5511) 40348268. E-mail: shimizu@ saofrancisco.edu.br 


\section{MATERIALS AND METHODS}

\section{Propolis extracts}

The sample of crude propolis was obtained near Tuiuti, in São Paulo state, where the vegetation was composed of native plants (including Baccharis dracunculifolia) plus orange and eucalyptus trees. The sample was ground to a particle size of 2 $\mathrm{mm}$ or less before extraction.

The sample was subjected to different extractive procedures in order to obtain extracts with different compositions. In the maceration procedure, approximately $30 \mathrm{~g}$ of ground crude propolis were added to $100 \mathrm{~mL}$ of each of the following solvents: pure absolute ethanol (Merck, Darmstadt, Germany), mixtures of absolute ethanol and distilled water containing 30\%, 50\% and $70 \%$ ethanol (v/v) and commercial grain alcohol (96\% v/v). The solutions were left at room temperature for 20 days and shaken once a day. In the Soxhlet extraction, approximately $30 \mathrm{~g}$ of ground crude propolis were added to $400 \mathrm{~mL}$ of absolute ethanol and refluxed for approximately 24 hours.

After filtration, the solvents were totally evaporated on a water bath, at temperatures not exceeding $50^{\circ} \mathrm{C}$. The dry extracts were then re-dissolved in $70 \%$ ethanol in order to obtain solutions containing $10 \%(\mathrm{w} / \mathrm{v})$ propolis extract.

\section{Thin layer chromatography and bioauthography}

Thin layer chromatographic (TLC) plates, composed of Merck Silica gel 60 GF 254, received $5 \mu \mathrm{L}$ of the propolis solutions (containing $500 \mathrm{mg}$ of propolis extract) placed at a distance of $1.5 \mathrm{~cm}$ of the lower edge of the plate. The mobile phase was hexane / ethylacetate / acetic acid (60:40:1, v/v). All solvents were purchased from Merck (Darmstadt, Germany). The plates were either visualised using sulphuric vanillin or biologically (bioauthography) to evaluate the activity of the propolis extracts.

Bioauthography was carried out after airing the TLC plates for over 8 hours. The plates were covered with $20 \mathrm{~mL}$ of sterile Mueller-Hinton agar at $45^{\circ} \mathrm{C}$ inoculated with the saline suspension of $S$. aureus, then incubated for $24 \mathrm{hs}$ at $37^{\circ} \mathrm{C}$. After this period each plate was covered with $5 \mathrm{~mL}$ of a $1 \%$ aqueous solution of 2,3,5 triphenyl tetrazolium chloride and incubated for up to 24 hours at $37^{\circ} \mathrm{C}$. Inhibition zones were visualised as clear areas against a red coloured background.

Preparative TLC plates with a thickness of $1 \mathrm{~mm}$ were prepared using the same stationary and mobile phases as above, with the objective of isolating the components of propolis that inhibited the growth of $S$. aureus. These areas were scraped from the plates, the substances eluted from the silica with methanol and identified by HPLC.

\section{High performance liquid chromatography}

Analytical HPLC was run on HPLC (Merck-Hitachi, Darmstadt, Germany), equipped with a pump (model L-6200,
Merck-Hitachi) and a diode array detector (L-3000, MerckHitachi). Separation was achieved on a Lichrochart 125-4 column (Merck, Darmstadt, Germany) (RP-18, $12.5 \times 0.4 \mathrm{~cm}, 5 \mu \mathrm{m}$ particle size) using water, formic acid $(95: 5, \mathrm{v} / \mathrm{v})($ solvent $\mathrm{A})$ and methanol (solvent B). The elution was carried out with a linear gradient and a flow rate of $1 \mathrm{~mL} / \mathrm{min}$. The detection was monitored at 280 and $340 \mathrm{~nm}$ and the components identified by comparison with standards acquired commercially or isolated during previous work (13).

\section{Microorganisms}

The Gram-positive bacteria used in these tests were obtained from $24 \mathrm{~h}$ cultures and suspended in sterile saline solution to obtain concentrations of approximately $10^{8} \mathrm{CFU} / \mathrm{mL}$, by comparison with the McFarland tube no. 1. The following species were tested: Staphylococcus aureus (sp., 13150, 6534), Staphylococcus epidermidis (A, B, 25212, 12228), Streptococcus pyogenes (sp., T23, 1500), Streptococcus mutans (sp., 1910), Streptococcus salivarius (sp., 0365) and Streptococcus sobrinus.

\section{Antimicrobial assays}

The following methods were used to evaluate the activity of the propolis extracts. All tests were performed in duplicate, using a 70\% ethanolic solution without propolis as a control to test the inhibitory effect of the solvent.

Agar plate diffusion tests, using paper disks. The plates were prepared using $20 \mathrm{~mL}$ of sterile Mueller-Hinton agar (Merck, Darmstadt, Germany). The surface of the plates was inoculated using a sterile swab containing the saline suspension of bacteria and allowed to dry. Previously prepared sterile paper disks, 6.0 $\mathrm{mm}$ in diameter, containing $10 \mathrm{mg}$ of propolis extract were put on the agar surface. The plates were incubated at $37^{\circ} \mathrm{C}$ and observed after 24 hours for clear inhibition zones around the disks.

Agar plate diffusion tests, using steel cylinders. The plates were prepared using $20 \mathrm{~mL}$ of sterile Mueller-Hinton agar. The surface of the plates was inoculated using a sterile swab containing the saline suspension of bacteria and allowed to dry. Sterile steel cylinders (with internal diameter of 5.7 and external diameter of $8.0 \mathrm{~mm}$ ) were placed on the surface and filled with $100 \mathrm{~mL}$ or $200 \mathrm{~mL}$ of the ethanolic propolis solutions (containing $10 \mathrm{mg}$ and $20 \mathrm{mg}$ of propolis extract, respectively). The plates were incubated at $37^{\circ} \mathrm{C}$ and observed after 24 hours for clear inhibition zones around the cylinders.

Serial dilution in tubes. Serial dilution was carried out using sterile Mueller-Hinton broth (Merck, Darmstadt, Germany) in order to obtain several concentrations between 20.0 and $0.6 \mathrm{mg}$ of propolis extract per $\mathrm{mL}$ of broth. The tubes were inoculated with $20 \mu \mathrm{L}$ of the bacteria suspension per $\mathrm{mL}$ of broth, homogenised and incubated at $37^{\circ} \mathrm{C}$ for 24 hours. After incubation, $50 \mu \mathrm{L}$ were taken from each tube and inoculated in 
a second tube containing $1 \mathrm{~mL}$ of sterile Mueller-Hinton broth, homogenised and incubated for another 24 hours at $37^{\circ} \mathrm{C}$. The Minimal Bactericidal Concentration (MBC) was determined as the lowest concentration of propolis for which no growth was observed in the second set of tubes.

\section{Statistical analysis of data}

The results obtained by serial dilution in tubes were analysed by Principal Component Analysis (PCA) using the 2.60 version of the Pirouette software from Infometrix (Woodville, WA, USA). PC1 x PC2 were able to explain $58 \%$ of the total variance in the data.

\section{RESULTS}

TLC plates compared the compositions of the propolis extracts (Fig. 1). The number of components in the propolis extracts increased proportionally to the ethanolic concentration in the solvent used for extraction. Therefore the extracts obtained using $30 \%$ ethanol contained only the most polar compounds, followed by those obtained using 50\% ethanol. The samples extracted with $70 \%$ ethanol were similar in

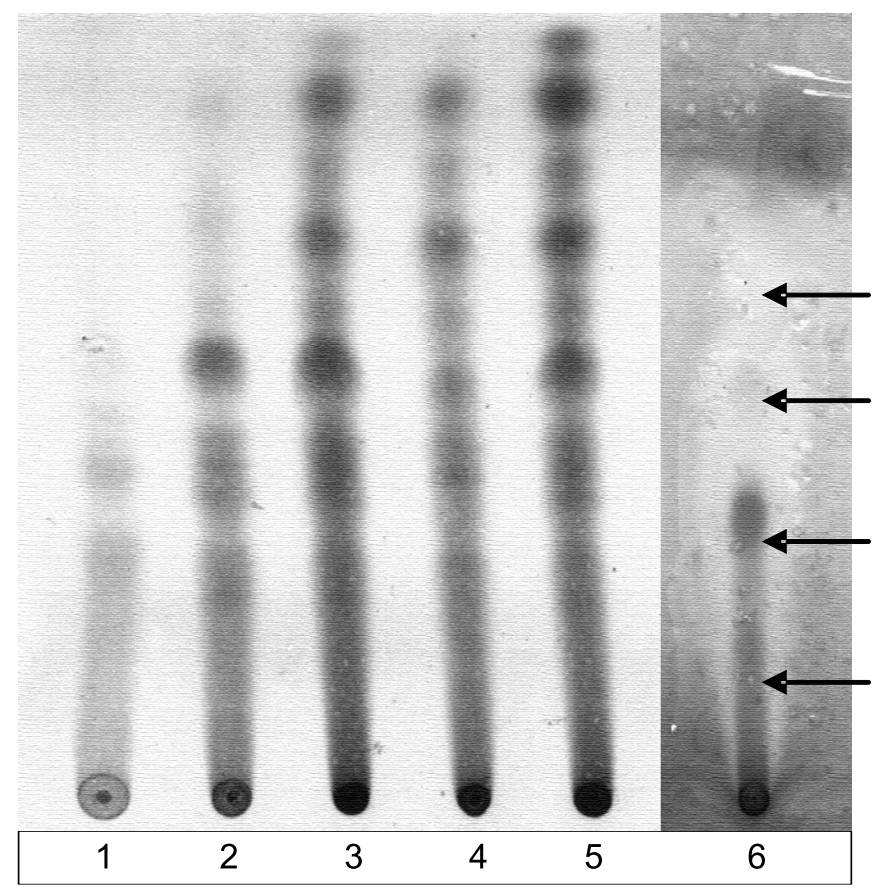

Figure 1. TLC plate of propolis samples extracted with: 1) $30 \%$ ethanol; 2) 50\% ethanol; 3) 70\% ethanol; 4) grain alcohol and 5) absolute ethanol, visualized using sulphuric vanillin and 6) bioauthography of a sample extracted with $70 \%$ ethanol (growth inhibition zones for S.aureus indicated by arrows). composition with the ones extracted with absolute ethanol and grain alcohol. Bioautography of the TLC plate (Fig. 1) shows a large area containing substances that inhibited the growth of $S$. aureus over the region containing the components with high and medium polarity.

The HPLC analysis of the substances obtained from this area indicated the presence of the following compounds: 2,2 dimethyl-6-carboxyethenyl-2H-1-benzopyran; 6-propenoic-2,2dimethyl-8-prenyl-2H-1-benzopyranic acid; 3,5-diprenyl-4hydroxycinnamic acid; 3-prenyl-4-hydroxycinnamic acid; caffeic acid; p-coumaric acid; kaempferol and several incompletely identified derivatives of these substances.

For the agar diffusion test with disks and cylinders, the propolis extracts that resulted in the largest growth inhibition zones were those extracted with $30 \%$ ethanol and $50 \%$ ethanol (Fig. 2). The growth inhibition zones of the other extracts were consistently smaller. All the propolis extracts tested showed greater growth inhibition zones than the control. In the agar diffusion test with paper disks the control disks prepared with $70 \%$ ethanol did not produce growth inhibition zones. In the agar diffusion tests using cylinders, the control cylinders containing $100 \mu \mathrm{L}$ or $200 \mu \mathrm{L}$ of $70 \%$ ethanol per cylinder, showed growth inhibition only within the cylinder itself, which was considered as no inhibition.

The results of serial dilution in tubes (Table 1) show that the bactericidal activity of the samples extracted with $50 \%$ ethanol was the greatest, followed by those extracted with $70 \%$ ethanol and grain alcohol, then absolute alcohol by Soxhlet extraction and maceration. The extracts obtained using 30\% ethanol showed the weakest bactericidal activity. The control tubes containing only $70 \%$ ethanol did not inhibit the growth of bacteria in the concentrations tested.

PCA analysis of these results divided the extracts into three groups; the first group containing only the extract obtained using $50 \%$ ethanol as the solvent; the intermediate group composed of the extracts obtained using 70\% ethanol, grain alcohol and absolute alcohol by Soxhlet extraction and maceration, and the last group containing the extract obtained using 30\% ethanol. Due to the variation in the susceptibility of individual strains to propolis, resulting in large standard deviations, no other statistical method could be applied.

\section{DISCUSSION}

Bioauthography of the TLC plate (Fig. 1) shows a large area containing substances that inhibited the growth of $S$. aureus over the region containing the components with high and medium polarity. These are the components extracted preferentially using $50 \%$ ethanol as the solvent, which explains why this extract shows the lowest MBC values. Although differences in susceptibility to propolis in the bacteria tested resulted in $\mathrm{MBC}$ values ranging from 2.5 and $20.0 \mathrm{mg} / \mathrm{mL}$, one 


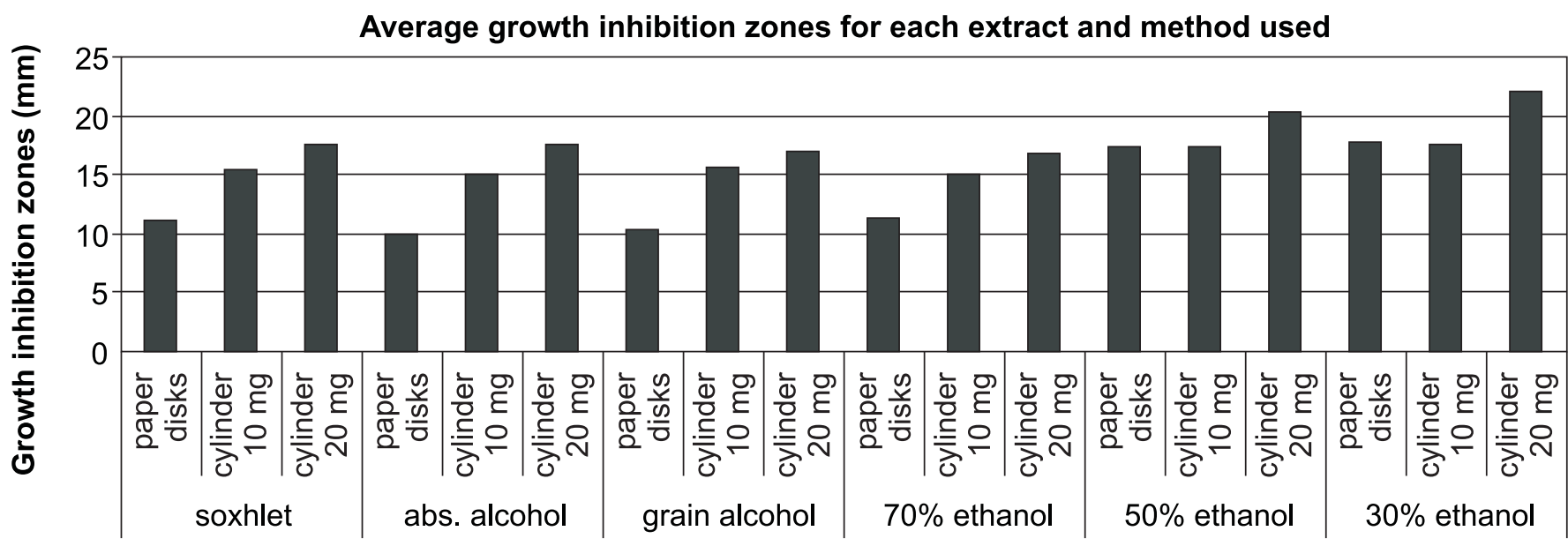

Extract and method used

Figure 2. Average growth inhibition zones in $\mathrm{mm}$, of the strains of Gram-positive bacteria tested by agar plate diffusion using paper disks with $10 \mathrm{mg}$ propolis extracts and cylinders containing 10 or $20 \mathrm{mg}$ propolis extracts.

Table 1. Minimal Bactericidal Concentration $(\mathrm{MBC}-\mathrm{mg} / \mathrm{mL})$ of the six-propolis extracts tested by serial dilution in tubes, for the 15 strains of Gram-positive bacteria.

\begin{tabular}{lrrrrrr}
\hline & \multicolumn{2}{c}{ Propolis } & \multicolumn{2}{c}{ Extracted } & \multicolumn{3}{c}{ With } \\
\cline { 2 - 6 } \multicolumn{1}{c}{ Bacteria } & soxhlet & abs.alcohol & grain alcohol & $70 \%$ ethanol & $50 \%$ ethanol & $30 \%$ ethanol \\
\hline S. aureus 13150 & 5.0 & 10.0 & 5.0 & 5.0 & 5.0 & 10.0 \\
S. aureus & 10.0 & 10.0 & 5.0 & 10.0 & 2.5 & 10.0 \\
S. aureus 6534 & 2.5 & 5.0 & 5.0 & 2.5 & 2.5 & 5.0 \\
S. epidermidis 25212 & 2.5 & 2.5 & 2.5 & 5.0 & 2.5 & 5.0 \\
S. epidermidis 12228 & 5.0 & 10.0 & 10.0 & 5.0 & 5.0 & 10.0 \\
S. epidermidis A & 2.5 & 5.0 & 5.0 & 5.0 & 2.5 & 5.0 \\
S. epidermidis B & 2.5 & 5.0 & 2.5 & 2.5 & 2.5 & 5.0 \\
S. pyogenes & 10.0 & 10.0 & 10.0 & 10.0 & 10.0 & 10.0 \\
S. pyogenes T23 & 10.0 & 5.0 & 5.0 & 5.0 & 5.0 & 10.0 \\
S. pyogenes 1500 & 5.0 & 5.0 & 5.0 & 5.0 & 5.0 & 10.0 \\
S. mutans 1910 & 10.0 & 10.0 & 10.0 & 5.0 & 5.0 & 10.0 \\
S. mutans & 2.5 & 10.0 & 5.0 & 5.0 & 5.0 & 10.0 \\
S. salivarius 0365 & 5.0 & 10.0 & 5.0 & 10.0 & 5.0 & 20.0 \\
S. salivarius & 10.0 & 5.0 & 5.0 & 5.0 & 5.0 & 10.0 \\
S. sobrinus & 10.0 & 10.0 & 10.0 & 10.0 & 5.0 & 20.0 \\
Average & 6.2 & 7.5 & 6.0 & 6.0 & 4.5 & 10.0 \\
\hline
\end{tabular}

could observe that the extract obtained using $50 \%$ ethanol had the lowest average MBC, therefore was the most active extract. PCA analysis of the data confirmed that this extract stood out from the group of intermediate activity (extracted with $70 \%$ ethanol, grain alcohol and absolute ethanol by maceration and Soxhlet).

Of the components of propolis identified by HPLC, pcoumaric acid and caffeic acid have been determined previously 
in Brazilian propolis (2) as well as kaempferol (3). Several compounds are known for their antibacterial activity. Aga et al. (1) determined the activity of 2,2 dimethyl-6-carboxyethenyl2H-1-benzopyran, 3-prenyl-4-hydroxycinnamic acid and 3,5diprenyl-4-hydroxycinnamic acid against a series of bacteria. Marcucci et al. (13), have determined the antibacterial activity of 2,2 dimethyl-6-carboxyethenyl-2H-1-benzopyrane, 6propenoic-2, 2-dimethyl-8-prenyl-2H-1-benzopyranic acid and 3,5-diprenyl-4-hydroxycinnamic acid against $S$. aureus.

The bactericidal activity of this sample of Brazilian propolis was due to the combined effect of several components with antibacterial activity. Other substances that were not completely identified, but eluted from the area showing bactericidal activity, could also be contributing to the bactericidal effect. Further studies will be necessary to determine these substances and their activity.

The results of the serial dilution and agar plate diffusion tests were contradictory, as the serial dilution test indicated the $30 \%$ ethanolic extract as the least effective and the agar diffusion tests indicated this same extract to be the most effective. The results of the agar diffusion tests were directly influenced by the hydro-solubility of the components of the propolis extracts tested. The extracts containing mainly hydro-soluble components (those extracted with 30\% and 50\% ethanol), diffused better in the agar plate and resulted in larger zones of growth inhibition.

Comparing the results of the plate diffusion tests (Fig. 2) the effect of the solvent on the diffusion of the components of propolis could be observed. The growth inhibition zones of the cylinders containing $10 \mathrm{mg}$ of propolis extracts dissolved in $70 \%$ ethanol were consistently larger than the zones obtained using paper disks with the same amount of propolis whose solvent had been evaporated, clearly demonstrating the effect of the hydro-alcoholic solvent on the diffusion of the components of propolis in the agar plate. The growth inhibition zones observed using cylinders containing $20 \mathrm{mg}$ of propolis extracts in $200 \mathrm{~mL}$ of solvent were larger, but not the double, of those observed using $10 \mathrm{mg}$ of propolis extracts.

Authors studying European propolis using plate diffusion tests obtained quite varied results. Metzner et al. (14) used agar diffusion in plates with cylinders, noting that the small inhibition zones were probably due to the low diffusion rate of the components of propolis in agar. Brumfitt et al. (5), reported inhibition zones of $13 \mathrm{~mm}$ for $S$. aureus and S. epidermidis, but found no activity against species of streptococci. On the other hand Dobrowolsky et al. (6) reported inhibition zones of $16 \mathrm{~mm}$ for both S. aureus and S. pyogenes.

The results of tests evaluating propolis from other parts of the world are difficult to compare. Paper disks were used by Ikeno et al. (10) to measure the anti-bacterial activity of Chinese and Japanese propolis, relating inhibition zones ranging from 6.0 to over $8.0 \mathrm{~mm}$ for $S$. sobrinus and of 5.5 to $6.8 \mathrm{~mm}$ for $S$. mutans. Nieva Moreno et al. (15) measured inhibition zones of over $10 \mathrm{~mm}$ for $S$. aureus and of under $10 \mathrm{~mm}$ for $S$. pyogenes, with paper disks with Argentine propolis. Park and Ikegaki (17) used plate diffusion and $5 \mathrm{~mm}$ paper disks to evaluate the antimicrobial activity of extracts of Brazilian propolis, reported inhibition zones ranging from 0.5 to $1.5 \mathrm{~mm}$ beyond the edge of the disks. Koo et al. (11) used agar diffusion with eight mm steel cylinders to measure the inhibition of oral bacteria by Brazilian propolis, reporting average inhibition zones of 2.00 $2.17 \mathrm{~mm}$ beyond the perimeter of the cylinder for $S$. mutans and of $2.25 \mathrm{~mm}$ for S. sobrinus. On the whole, one cannot conclude if the variation in results was due to the method employed or actually a result of the activity of the propolis samples tested.

Serial dilution in tubes showed more consistent results, which were in agreement with the results of the chromatographic analyses. The use of 30\% ethanol extracted some of the polar compounds responsible for the bactericidal activity of propolis, but not all of them, resulting in an extract with weak bactericidal activity. On the other hand, 50\% ethanol extracted all the compounds with bactericidal activity, but none of the less polar inactive ones, resulting in a highly bactericidal extract. The extracts obtained using ethanolic concentrations between 70 and $100 \%$ contained components with and without bactericidal activity, and therefore did not show such strong activity as the $50 \%$ ethanolic extract. This test was apparently not influenced by the solubility of the active components in the broth. Using serial dilution in tubes for European propolis, MBC of $1.5 \mathrm{mg} /$ $\mathrm{mL}$ for $S$. aureus (14) and of $3.0 \mathrm{mg} / \mathrm{mL}$ for $S$. aureus and $S$. epidermidis (8) were found. Different samples of Brazilian propolis evaluated using this method have shown similar results with MBC for S. aureus of $4.0 \mathrm{mg} / \mathrm{mL}$ (20), $6.0 \mathrm{mg} / \mathrm{mL}$ (7) and 4.0 $-9.0 \mathrm{mg} / \mathrm{mL}$ (16) reported. For S. epidermidis, MBC of 4.0 - 10.0 $\mathrm{mg} / \mathrm{mL}$ and for $S$. mutans, MBC of $2.0-5.0 \mathrm{mg} / \mathrm{mL}$ (16) have been found. These results are in the same range as those reported in this work.

Bosio et al. (4) used both dilution and diffusion methods to study the activity of Italian propolis against $S$. pyogenes concluding that, whereas the results of the agar diffusion tests with disks were not suitable for comparing specimens, the agar dilution tests gave results that corresponded to the results of the HPLC tests.

The results of this paper, as well as the results of other authors, indicate that serial dilution in tubes is the best method for the evaluation of the bactericidal activity of propolis samples. Agar plate diffusion tests are strongly influenced by the solubility of the components of propolis in agar, leading to incorrect results. This method should not be used for the comparison of samples of different hydro-solubility nor for the evaluation of poorly hydro-soluble samples.

The combination of chromatographic techniques (TLC, HPLC and bioauthography) with serial dilution in tubes was capable of identifying the propolis extract with the greatest 
bactericidal activity, analysing its composition and identifying some of the components responsible for this activity. This demonstrates the importance of using the correct combination of microbiological and chromatographic analyses.

\section{ACKNOWLEDGEMENTS}

Partial support for this work by Fundação de Amparo à Pesquisa do Estado de São Paulo (FAPESP) contracts no. 98/ 11719-4 and 95/09306-5 and Universidade São Francisco (PROPEP) is gratefully acknowledged.

\section{RESUMO}

\section{Análise da composição de extratos de própolis brasileiros por cromatografia e avaliação de sua atividade in vitro sobre bactérias}

Própolis brasileira, proveniente do estado de São Paulo, foi submetida à extração usando vários solventes, resultando em extratos com diferentes composições. Estes extratos foram submetidos à Cromatografia em Camada Delgada (CCD). Análise bioautográfica das placas de CCD permitiu identificar as frações com atividade antimicrobiana, que foram então analisadas por Cromatografia Líquida de Alta Eficiência (CLAE). Ensaios in vitro freqüentemente utilizados para avaliar a atividade de própolis frente a bactérias Gram-positivas foram comparados para determinar qual renderia os resultados mais consistentes. A atividade bactericida destes extratos foi analisada por Diluição Seriada em Tubos e por testes de Difusão em Agar. O método de Diluição em Tubos permitiu obter os resultados mais consistentes e a Concentração Bactericida Mínima dos extratos variou entre 2,5 e $20,0 \mathrm{mg} / \mathrm{mL}$, para as espécies de bactérias Gram-positivas testadas. Os resultados do método de Difusão em Agar foram diretamente proporcionais à hidrossolubilidade dos extratos, e não avaliaram a atividade bactericida corretamente. A atividade bactericida desta amostra resultou da combinação de vários componentes, identificados por CLAE, que foram extraídos preferencialmente usando etanol $50 \%$ como solvente.

Palavras-chave: própolis, cromatografia em camada delgada, cromatografia líquida de alta eficiência, bioautografia, métodos de extração, concentração bactericida mínima

\section{REFERENCES}

1. Aga, H.; Shibuya, T.; Sugimoto, T.; Kurimoto, M.; Nakajima, S Isolation and identification of antimicrobial compounds in Brazilian propolis. Biosci. Biotech. Biochem., 58: 945-946, 1994.
2. Bankova, V.; Christov, R.; Kujumgiev, A.; Marcucci, M.C.; Popov, S. Chemical composition and antibacterial activity of Brazilian propolis, Z. Naturforschung., 50C: 167-172, 1995.

3. Bonvehi, J.S.; Coll, F.C.; Jordà, R.E. The composition, active components and bacteriostatic activity of propolis in dietetics. $J$. Amer. Oil Chem., 71: 529-532, 1994.

4. Bosio, K.; Avanzini, C.; D’Avolio, A.; Ozino, O.; Savoia, D. In vitro activity of propolis against Streptococcus pyogenes, Lett. Appl. Microb., 31: 74-177, 2000.

5. Brumfit, W.; Hamilton, J.M.T.; Franklin I. Antibiotic activity of natural products: 1. Propolis. Microbios, 62: 19-22, 1990.

6. Dobrowolski, J.W.; Vohora, S.B.; Sharma, K.; Shah, S.A.; Naqvi, S.A.H.; Dandiya, P.C. Antibacterial, antifungal, antiamoebic, antiinflamatory and antipyretic studies on propolis bee products. $J$. Ethnopharmacol., 35: 77-82, 1991.

7. Fernandes Jr., A.; Lopes, C.A.M.; Sforcin, J.M.; Funari, S.R.C. Population analysis of susceptibility to propolis in reference standards of Staphylococcus aureus and Escherichia coli. J. Ven. Anim. Toxins., 3: $15-18,1997$

8. Grange, J.M.; Davey, R.W. Antibacterial properties of propolis (bee glue). J. Royal Soc. Méd., 83: 109-110, 1990.

9. Greenaway, W.; Scaysbrook, T.; Whatley, F.R. The composition and plant origins of propolis. Bee World, 71: 107-118, 1990.

10. Ikeno, K.; Ikeno, T.; Miyazawa, C. Effects of propolis on dental caries in rats. Caries Res., 25: 347-351, 1991.

11. Koo, H.; Gomes, B.P.F.A.; Rosalen, P.L.; Ambrosano, G.M.B.; Park, Y.K.; Cury, J.A. In vitro antimicrobial activity of propolis and Arnica montana against oral pathogens. Arch. Oral Biol., 45: 141-148, 2000.

12. Marcucci, M.C.; Bankova, V.S. Chemical composition, plant origin and biological activity of Brazilian propolis. Curr. Phytochem., 2 $115-123,1999$

13. Marcucci, M.C.; Ferreres, F.; Garcia-Viguera, C.; Bankova, V.; De Castro, S.L.; Dantas, A.P.; Valente, P.H.M.; Paulino, N. Phenolic compounds from Brazilian propolis with pharmacological activities. J. Ethnopharmacol., 74: 105-112, 2001.

14. Metzner J.; Bekemeier H.; Paintz M.; Schneidewind, E. On the antimicrobial activity of propolis and propolis constituents Pharmazie, 34: 97-102, 1979.

15. Nieva Moreno, M.I.; Isla, M.I.; Cudmani, N.G.; Vattuone, M.A.; Sampietro, A.R. Screening of the antibacterial activity of Amaicha del Valle (Tucumán, Argentina) propolis. J. Ethnopharmacol., 68 97-102, 1999

16. Ota, C.; Valente, P.H.M.; Unterkircher, C.S.; Shimizu, M.T. Effects of propolis on bacteria isolated from oral cavity. Lecta, 16: 73-77, 1998

17. Park, Y.K.; Alencar, S.M.; Aguiar, C.L. Botanical origin and chemical composition of Brazilian propolis. J. Agric. Food Chem., 50: 25022506, 2002

18. Park, Y.K.; Ikegaki, M. Preparation of water and ethanolic extracts of propolis and evaluation of the preparations. Biosci. Biotech. Biochem., 62: 2230-2232, 1998.

19. Sawaya, A.C.H.F.; Palma, A.M.; Caetano, F.M.; Marcucci, M.C.; Cunha, I.B.S.; Araujo, C.E.P.; Shimizu, M.T. Comparative study of in vitro methods used to analyse the activity of propolis extracts with different compositions against species of Candida. Lett. Appl. Microb., 35: 205-207, 2002.

20. Sforcin, J.M.; Fernandes Jr., A.; Lopes, C.A.M.; Bankova, V.; Funari, S.R.C. Seasonal effect on Brazilian propolis antibacterial activity. $J$. Ethnopharmacol., 73: 243-249, 2000.

21. Tomás-Barberán, F.A.; Garcia-Viguera, C.; Vit-Olivier, P.; Ferreres, F.; Tomas-Lorente, F. Phytochemical evidence for the botanical origin of tropical propolis from Venezuela. Phytochemistry, 34: 191$195,1993$. 